\title{
TRZEŹWOŚĆ GŁÓWNYM ZAŁOŻENIEM I ZADANIEM MAKSYMILIAŃSKIEGO RUCHU TRZEŹWOŚCl
}

DOI: http://dx.doi.org/10.12775/TiCz.2017.052

\section{WPROWADZENIE}

Kościół, którego misja zbawcza dotyczy nie tylko wieczności człowieka, ale także pełni jego rozwoju doczesnego, świadom zagrożeń wynikających $z$ nadużywania alkoholu zawsze podejmował działania duszpasterskie prowadzące do wykorzenienia pijaństwa i ugruntowania cnoty trzeźwości. Należy zauważyć w tym miejscu słuszność nauczania Kościoła, ponieważ nadużywanie alkoholu niszczy człowieka w całym jego wymiarze: fizycznym, psychicznym i duchowym - zarówno osobę pijącą alkohol, jak również całą jej rodzinę, powodując zaburzenia w sferze fizyczno-psychicznej, a szczególnie w sferze duchowej, z którą związane są takie podstawowe wartości, jak: miłość, ufność, wolność, dojrzałość, odpowiedzialność - kształtujące człowieka, jego właściwe relacje do siebie

* Janina Bokun, magister teologii, doktorantka w Katedrze Teologii Praktycznej WT UMK. Działa w Duszpasterstwie Trzeźwości Diecezji Gdańskiej na rzecz ludzi dotkniętych problemem alkoholizmu (bokunnina@interia.pl). 
samego, drugiej osoby, do odkrywania i doświadczania miłości Bożej. Do tej refleksji skłania fakt, że w Polsce problem uzależnienia od alkoholu, jego zgubny wpływ na jednostkę i rodzinę, a przez to i na społeczeństwo jest szczególnie uwidoczniony.

W naszej Ojczyźnie nadużywanie alkoholu prowadzi do wielu nieszczęść, zarówno rodzinnych, jak i społecznych, dlatego w każdej epoce istnieją ludzie walczący z tym nałogiem. Jednak zdecydowane działania w tym zakresie zaczęto prowadzić przed pierwszą wojną światową. Troska Kościoła o trzeźwość Narodu Polskiego szczególnie objawia się w zakładaniu różnego rodzaju bractw trzeźwościowych działających do drugiej wojny światowej. Chociaż po wojnie praca ta zostaje przez władze państwowe rządzące krajem w tamtym okresie zawieszona, to jednak Kościół w trosce o człowieka, o jego rozwój w całym wymiarze cielesno-duchowym i realizację życia w pełni ewangelicznego zgodnie z nauką Soboru Watykańskiego II oraz w obliczu narastającego alkoholizmu, prowadzi różne formy działalności trzeźwościowej. Jedną z takich form działalności jest Ruch Trzeźwości im. św. Maksymiliana Kolbego działający przy parafiach, reaktywowany przez Episkopat Polski w 1982 roku na Jasnej Górze, którego celem jest walka z pijaństwem oraz szerzenie trzeźwości kształtującej w człowieku jego godność, miłość, wolność i odpowiedzialność. MRT jest żywą odpowiedzią Kościoła w Polsce na prośbę dwóch wielkich Polaków: sługi bożego ks. kardynała Stefana Wyszyńskiego, któremu sprawa trzeźwości Narodu Polskiego była szczególnie bliska, o której mawiał: „przez abstynencję wszystkich kapłanów do trzeźwości całego Narodu"1, oraz na prośbę błogosławionego Jana Pawła II wyrażoną do Polaków w dniu 23 X 1978 roku - aby skutecznie przeciwstawiali się obyczajom zagrażającym człowiekowi, jego rodzinie i narodowi².

\section{Z DZIEJÓW MRT W POLSCE}

O zorganizowanym ruchu trzeźwościowym związanym z walką przeciwko pladze pijaństwa można mówić wówczas, gdy tworzy go grupa

${ }^{1}$ Por. Komisja Episkopatu Polski ds. Trzeźwości, Ruch Trzeźwości im. św. Maksymiliana Kolbego nadzieja ratowania Narodu, s. 4.

2 Por. Jan Paweł II, List do Polaków. Zachowajcie wierność Chrystusowi, Jego Krzyżowi, Kościołowi. 24 X 1978, s. 23. 
ludzi mających wspólny cel i program. Dlatego, chociaż na przestrzeni wieków było wielu ludzi przestrzegających przed zgubnymi skutkami upijania się i podkreślającymi wartość trzeźwości, za pierwszy zorganizowany ruch należy uznać powołany w 1808 roku w Moreau, w stanie Nowy Jork, w Ameryce Północnej. Było to towarzystwo przeciwalkoholowe, w którym preferowano zupełną abstynencję, a niekiedy umiarkowane spożycie alkoholu3 ${ }^{3}$ W 1813 roku w Bostonie powstało pierwsze na świecie stowarzyszenie abstynenckie, skąd rozprzestrzeniło się na kraje anglosaskie, a następnie dotarło do państwa niemieckiego i innych krajów nadbałtyckich. W Polsce rozwój Bractw Trzeźwości i Towarzystw Wstrzemięźliwości nastąpił po 1830 roku, jako reakcja obronna społeczeństwa polskiego na rozpijanie narodu przez zaborców. Inicjatywy Bractw na rzecz trzeźwości Polaków były podejmowane we wszystkich zaborach ${ }^{4}$.

W Królestwie Kongresowym od 1833 roku bractwa trzeźwości były organizowane przy kościołach parafialnych. W Archidiecezji Warszawskiej inicjatorem i propagatorem powstawania bractw trzeźwości, które walczyły z alkoholizmem wśród społeczeństwa, był arcybiskup Zygmunt Szczęsny Feliński. Księża propagujący trzeźwość mieli świadomość, że ruch trzeźwościowy nie rozwinie się bez osobistego przykładu abstynencji, toteż w 1910 roku we Włocławku założyli „Bractwo Zupełnej Wstrzemięźliwości” obejmujące księży i kleryków. W 1907 roku w Warszawie powstało stowarzyszenie „Przyszłość”, które swą działalność antyalkoholową oparło głównie na czynnikach związanych z przyrodą. Działało również Towarzystwo Higieniczne, które utworzyło specjalny wydział przeciwalkoholowy, a w 1909 roku zorganizowało pierwszą w Polsce wystawę przeciwalkoholową. Na terenie Królestwa działały również organizacje przeciwalkoholowe skupiające młodzież wiejską ${ }^{5}$.

${ }^{3}$ Por. R. Radziłłowicz, Alkohologia, książka dla walczących z alkoholizmem, Warszawa 1928, s. 144; E. Walewander, Wychowanie chrześcijańskie w nauczaniu i praktyce Kościoła Katolickiego na ziemiach polskich w II połowie XIX w., Lublin 1994, s. 121.

${ }^{4}$ Por. M. Dziewiecki, Nowe przesłanie nadziei, Warszawa 2000 , s. 304. Zob. także: P. Romaniuk, W trosce o trzeźwość Narodu. Sylwetki najwybitniejszych działaczy trzeźwościowych XIX i XX w., t. 2, Warszawa 1996, s. 27.

5 Por. Wł. Padacz, Katolicka akcja trzeźwościowa w Polsce porozbiorowej, „Homo Dei”, 1 (1963), s. 27-28; M. Dziewiecki, Nowe przesłanie nadziei, s. 305. 
W Poznańskiem i na Pomorzu walkę z alkoholizmem podjęli katolicy świeccy. Wiedząc, jaką klęską jest dla Polaków pijaństwo, powołali w 1837 roku „Towarzystwo Wstrzemięźliwości” w Sztumie. Kolejne powstawały w Toruniu, Nowym Mieście, Chełmży i szeregu miasteczek pomorskich, a także w powiatach poznańskich i w Gnieźnie. W 1868 roku, dzięki biskupowi M. Ledóchowskiemu powstały w parafiach archidiecezji gnieźnieńskiej i diecezji poznańskiej liczne bractwa trzeźwościowe, których działalność w 1870 roku zostaje ograniczona z powodu wojny i aresztowania arcybiskupa Ledóchowskiego. Pomimo wspomnianych przeszkód, w 1887 roku powstało „Towarzystwo Szerzenia Wstrzemięźliwości”, następnie podobna organizacja pod nazwą „Jutrzenka”, a także „Związek Księży Abstynentów na Diecezję Gnieźnieńską i Poznańską”. Na Pomorzu duchowieństwo utworzyło w 1913 roku „Bractwa Dzieciątka Jezus”, które niosły pomoc duchową dla katolickich ruchów trzeźwościowych ${ }^{6}$.

Na Śląsku Cieszyńskim i w Galicji szerzącemu się pijaństwu usiłowało zaradzić zarówno duchowieństwo katolickie, jak i protestanckie. Zaczęły powstawać przy parafiach, szczególnie miejskich, towarzystwa wstrzemięźliwości, oparte na statusach bractw kościelnych7\% W 1844 roku w Piekarach Śląskich ksiądz Ficek i zakonnik S. Brzozowski założyli Towarzystwo Wstrzemięźliwości, dzięki któremu około pół miliona osób z Górnego Śląska wyrzekło się picia alkoholu. Jednym z pionierów walki z alkoholizmem był proboszcz z Tych Śląskich, ks. Jan Kapica, który poprzez swoje porywające kazania przyczyniał się do powstania Bractw Trzeźwości, których członkowie nie tylko sami zachowywali wstrzemięźliwość, ale byli jej gorliwymi propagatorami w swoim otoczeniu. Ksiądz Kapica zdołał w ciągu trzech lat przeprowadzić w ponad 40 śląskich parafiach kilkudniowe misje o tematyce trzeźwościowej, pozyskując w ten sposób sojuszników do walki z pijaństwem. W Galicji w 1902 roku grupa Polaków założyła abstynenckie stowarzyszenie „Eleuteria” obejmujące swym zasięgiem cały zabór austriacki. W walce przeciwko pijaństwu

${ }^{6}$ Por. Wł. Padacz, Katolicka akcja trzeźwościowa, s. 27-29; B. Głodowski, Historia ruchów trzeźwościowych na Pomorzu, cz. 1, „Trzeźwymi Bądźcie”, 1 (2004), s. 15-17; B. Głodowski, Historia ruchów trzeźwościowych na Pomorzu, cz. 2, „Trzeźwymi Bądźcie”, 2 (2004), s. 30-32; B. Głodowski, Zaangażowanie duchowieństwa katolickiego w ruch trzeźwościowy na Pomorzu przed rokiem 1920, „Studia Gdańskie”, 26 (2007), s. 143-172.

7 Por. M. Dziewiecki, Katolicka akcja trzeźwościowa, s. 161. 
wsparcie okazał arcybiskup Bilczewski, który zachęcał duchowieństwo do zwrócenia bacznej uwagi na szerzące się pijaństwo i wynikające stąd grzechy. Również przeciwko pijaństwu występował ks. Markiewicz oraz brat Albert, który założył zgromadzenie zakonne dla ratowania biednych i nieszczęśliwych, szczególnie z powodu pijaństwa. W 1902 roku powstało towarzystwo poczwórnej dożywotniej wstrzemięźliwości „Eleusis” zrzeszające osoby świeckie i duchowne, które prowadziły pracę na rzecz abstynencji w zaborze austriackim i pruskim. W okresie niewoli podejmowano próby integracji ruchów przeciwalkoholowych z terenów trzech zaborów, jednak dopiero w wolnej Polsce, 18 kwietnia 1919 roku w Warszawie, powstało Polskie Towarzystwo Walki z Alkoholizmem o nazwie „Trzeźwość, jednoczące działaczy przeciwalkoholowych z byłych zaborów ${ }^{8}$.

W Polsce niepodległej okresu międzywojennego oprócz organizacji „Trzeźwość” działały również: Abstynencka Liga Kolejowców, Koło Lekarzy Abstynentów, Katolicki Związek Abstynentów, Polski Związek Księży Abstynentów, Związek Nauczycieli Abstynentów, Polska Liga Przeciwalkoholowa i wiele innych organizacji trzeźwościowych. W 1937 roku w Warszawie został zorganizowany XXI Międzynarodowy Kongres Przeciwalkoholowy połączony z I Międzynarodowym Katolickim Kongresem Przeciwalkoholowym. Okres międzywojenny to czas, w którym państwo i Kościół wzajemnie się wspierały w zwalczaniu plagi pijaństwa ${ }^{9}$.

Lata II wojny światowej zniweczyły działania polskiego ruchu przeciwalkoholowego, jednak walkę z rozpijaniem narodu podjęły władze Państwa Podziemnego. Trudne wojenne lata przetrwało wiele organizacji trzeźwościowych, które wznowiły swoją działalność zaraz po odzyskaniu wolności. W 1947 roku Episkopat Polski wydał list pasterski „O pijaństwie”, powstały też liczne bractwa trzeźwościowe. Nie przetrwały one jednak długo, ponieważ komunistyczne władze państwowe rozwiązały je, przejmując pełną kontrolę nad działalnością trzeźwościową i przeciwalkoholową. Powstała jedna, ściśle kontrolowana przez władze komunistyczne

8 Por. Wł. Padacz, Katolicka akcja trzeźwościowa, s. 30-33; M. Dziewiecki, Nowe przesłanie nadziei, s. 304-305.

9 Por. Zespół Apostolstwa Trzeźwości przy Konferencji Episkopatu Polski, Apostoł Trzeźwości. Vademecum duszpasterstwa trzeźwości, Płock 2007, s. 59-60; M. Dziewiecki, Katolicka akcja trzeźwościowa, s. 306; W. Chodźko, Walka $z$ alkoholizmem $w$ okresie między obu wojnami światowymi, „Roczniki UMCS”, 3 (1948), 2 SEC D, s. 87-93. 
organizacja pod nazwą „Główny Społeczny Komitet Przeciwalkoholowy”, którą w niedługim czasie przemianowano na „Społeczny Komitet Przeciwalkoholowy”. Od 1959 roku Społeczny Komitet Przeciwalkoholowy stał się stowarzyszeniem wyższej użyteczności publicznej, zyskując w ten sposób przywilej wyłącznego reprezentowania polskiego ruchu przeciwalkoholowego, co spowodowało zniknięcie na wiele dziesiątków lat autentycznego ruchu trzeźwościowego w Polsce ${ }^{10}$.

Ważnym wydarzeniem w latach 1956-1966 były Jasnogórskie Śluby Narodu i Wielka Nowenna, która stała się również wielkim wołaniem o trzeźwość narodu. W tym okresie podejmowana była niezależna działalność trzeźwościowa przez pojedyncze osoby, które były narażone na represje ze strony władz komunistycznych. Jedną z takich osób był ks. Franciszek Blachnicki, który utworzył Krucjatę Trzeźwości. Została ona przemianowana na Krucjatę Wstrzemięźliwości, masowy ruch przeciwalkoholowy promujący całkowitą abstynencję i obejmujący swym zasięgiem szerokie masy społeczne. Krucjata działała angażując w swoją działalność około tysiąca kapłanów, jednak w sierpniu 1960 roku ówczesne władze państwowe zlikwidowały ją, a ks. Blachnickiego aresztowały. W 1968 roku przy klasztorze Braci Mniejszych Kapucynów w Zakroczymiu powstał założony przez ojca Benignusa Ośrodek Apostolstwa Trzeźwości, który przetrwał pomimo licznych trudności stwarzanych przez władze komunistyczne i do dnia dzisiejszego prowadzi ogólnopolską duszpasterską działalność trzeźwościową. W 1970 roku powstała Komisja ds. Trzeźwości powołana przez Episkopat Polski, której celem była koordynacja pracy trzeźwościowej w Polsce ${ }^{11}$.

Dopiero jednak w latach osiemdziesiątych na fali ruchów społecznych i związanych z tym przemian politycznych w kraju, ruch trzeźwości zaczął masowo odradzać się, wzorując się na dawnych Bractwach Trzeźwości. Podczas Pierwszej Krajowej Pielgrzymki Trzeźwości, 19 IX 1982 roku, na Jasnej Górze proklamowany został Ruch Trzeźwości im. Świętego Maksymiliana Kolbego, który jest kontynuacją bractw trzeźwości, licznych stowarzyszeń trzeźwościowych i abstynenckich, skutecznie

10 Por. M. Dziewiecki, Katolicka akcja trzeźwościowa, s. 306-307.

11 Por. Apostoł Trzeźwości. Vademecum duszpasterstwa trzeźwości, Płock 2007, s. 60; M. Dziewiecki, Katolicka akcja trzeźwościowa, s. 306-307. 
walczących z pijaństwem w XIX i w pierwszej połowie XX wieku. Maksymiliański Ruch Trzeźwości jest również realizacją Jasnogórskich Ślubów Narodu obejmujących troskę o codzienne życie w trzeźwości Polaków oraz odpowiedzią na prośbę Jana Pawła II skierowaną do rodaków $23 \mathrm{X}$ 1978 roku w sprawie skutecznego przeciwstawiania się obyczajom zagrażającym człowiekowi ${ }^{12}$. Jak mawiał patron ruchu św. Maksymilian Kolbe: „Niećcie wszędzie miłość i ufność ku Maryi Niepokalanej, a ujrzycie że nawet $\mathrm{z}$ oczu najzatwardzialszych grzeszników popłyną łzy, opróżnią się więzienia, zwiększy się zastęp pracowników, a ogniska domowe zawonieją cnotą, pokój i szczęście wyniszczy niezgodę i ból”13. RTMK jest zatem zbiorowym, jednolicie zorganizowanym apostolskim działaniem tych, którym leży na sercu trzeźwość w Ojczyźnie oraz przywrócenie na właściwe i godne miejsce cnoty trzeźwości i abstynencji w życiu każdego człowieka, i jest jedną z form duszpasterstwa zwyczajnego. Działalność MRT jest inicjowana i prowadzona w oparciu o Kodeks Prawa Kanonicznego i Wytyczne Episkopatu Polski dla Kościelnej Działalności Trzeźwościowej, przyjęte przez Konferencję Episkopatu Polski w dniu 17 VI 1959 roku, a znowelizowanej 1 IV 1979 roku $^{14}$.

\section{GŁÓWNE CELE I ZADANIA MRT}

Główne cele i zadania MRT zostały zawarte w sformułowaniu zaczerpniętym z Wytycznych Episkopatu Polski dla Kościelnej Działalności Trzeźwościowej, które mówi: „przez dobrowolną, całkowitą abstynencję wielu do trzeźwości stanowej i zawodowej wszystkich"15. Zatem MRT

12 Por. Apostoł trzeźwości. Vademecum duszpasterstwa trzeźwości, Płock 2006, s. 28; M. Dziewiecki, Katolicka akcja trzeźwościowa, s. 308.

${ }^{13}$ Komisja Episkopatu Polski ds. Trzeźwości, Ramowy Regulamin Ruchu Trzeźwości im. św. Maksymiliana Kolbego, Warszawa 1986, s. 5.

${ }^{14}$ Por. Apostoł trzeźwości. Vademecum duszpasterstwa trzeźwości - 2006, s. 29; Komisja Episkopatu Polski ds. Trzeźwości, Ramowy Regulamin Ruchu Trzeźwości im. św. Maksymiliana Kolbego, s. 1.

${ }^{15}$ Komisja Episkopatu Polski ds. Trzeźwości, Ruch Trzeźwości im. św. Maksymiliana Kolbego nadzieją ratowania Narodu, s. 3. Zob. także: Komisja Episkopatu Polski, Wytyczne Episkopatu Polski dla Kościelnej działalności trzeźwościowej, Warszawa 1. IV. 1971, s. 1. 
opierając się na chrześcijańskich zasadach i obyczajach, ma na celu przede wszystkim utrwalanie trzeźwości i abstynencji, zwalczanie alkoholizmu i pijaństwa oraz innych uzależnień ${ }^{16}$.

Do głównych zadań RTMK należy ciągła troska o podnoszenie wiary i moralności społecznej parafian poprzez propagowanie cnoty trzeźwości i abstynencji, codzienna, stała realizacja Jasnogórskich Ślubów Narodu i Wytycznych Episkopatu Polski dla Kościelnej Działalności Trzeźwościowej w ramach zwyczajnego duszpasterstwa w Polsce, uwzględniająca wskazania Kościoła i jego Magisterium. W ramach powyższych zadań mieszczą się następujące treści, które MRT powinien realizować:

- budzenie szacunku dla godności człowieka i życia chrześcijańskiego poprzez propagowanie katolickich obyczajów, formowanie postaw i trzeźwych form współżycia między ludźmi, oraz zdecydowane zwalczanie pijackich zwyczajów i innych uzależnień;

- szerzenie słowem i pismem zagadnień z zakresu alkoholizmu, narkomanii, nikotynizmu i innych uzależnień, oraz wskazywanie na doniosłą rolę trzeźwości i abstynencji własnym przykładem;

- zdobywanie wśród wiernych i społeczeństwa zrozumienia, a także poparcia dla abstynencji i trzeźwości, jak również prowadzenie w tym względzie ciągłej formacji dla wszystkich grup ludności w parafii;

- popieranie społeczno-kulturowych przedsięwzięć Kościoła, oraz pozakościelnych instytucji, stowarzyszeń w walce o trzeźwość i abstynencję w życiu każdego człowieka, rodziny i Narodu;

- czuwanie nad przestrzeganiem Jasnogórskich Ślubów Narodu i Wytycznych Episkopatu dla Kościelnej Działalności Trzeźwościowej w życiu codziennym własnego środowiska, oraz dbanie o wykorzystanie stosownych przepisów prawnych w celu bardziej skutecznego zwalczania pijaństwa i alkoholizmu, oraz nikotynizmu i narkomanii, a także innych uzależnień ${ }^{17}$.

Podstawową zasadą działania Maksymiliańskiego Ruchu Trzeźwości jest fakt, że powstaje on i działa przy parafii. Członkiem Ruchu Trzeźwości

16 Por. Vademecum Apostolstwa Trzeźwości - 2006, s. 28-29.

${ }_{17}$ Por. Komisja Episkopatu Polski ds. Trzeźwości, Ramowy Regulamin Ruchu Trzeźwości im. św. Maksymiliana Kolbego, s. 6-9. 
im. św. Maksymiliana Kolbego zostaje się przez złożenie podczas specjalnego nabożeństwa przyrzeczenia abstynencji, wypełnienie i podpisanie deklaracji członkowskiej oraz wpisanie do Księgi Trzeźwości. Do ruchu można również przystąpić w Tygodniu Modlitw o Trzeźwość Narodu, w sierpniu - miesiącu trzeźwości i abstynencji, podczas misji, rekolekcji, odpustu parafialnego, a także $\mathrm{w}$ innym dowolnie wybranym przez siebie czasie w kościele lub innym miejscu, składając na ręce kapłana przyrzeczenie według właściwej formuły. Członkiem RTMK pozostaje się do końca życia, członkostwo ustaje z chwilą śmierci, ale bywa również tak, że członek sam dobrowolnie występuje $\mathrm{z}$ ruchu lub prawomocnie zostaje wykluczony za lekceważenie i nieprzestrzeganie regulaminu, szczególnie za złamanie przyrzeczenia trzeźwości i brak poprawy po wcześniejszych napomnieniach.

Wszystkie osoby należące do Ruchu Trzeźwości, a więc sympatycy, przyjaciele oraz apostołowie trzeźwości, zobowiązują się do trzeźwości i dobrowolnej abstynencji od wszystkich napojów alkoholowych na czas określony lub na całe życie. Członkowie MRT wszystkich trzech wyżej wymienionych kategorii, oprócz zachowania dobrowolnej trzeźwości i abstynencji, zobowiązani są do:

- codziennego polecania i zawierzania Bogu i Matce Bożej: siebie, rodziny, przyjaciół, parafii, Kościoła, Ojczyzny przez odmawianie modlitwy „Ojcze nasz” oraz „Pod Twoją obronę” lub „Zdrowaś Maryjo” dodając na końcu: św. Janie Chrzcicielu patronie trzeźwości, św. Maksymilianie patronowie apostolstwa trzeźwości módlcie się za nami;

- czynnego udziału w comiesięcznych spotkaniach, Mszy św., nabożeństwach, a także udział w uroczystościach RTMK i współpracy w środowiskowym apostolstwie trzeźwości;

- wzbogacania swojego życia duchowego i religijnego przez rozważanie i przestrzeganie przykazań Bożych i Kościelnych, czytania i rozważania Pisma św., podejmowania umartwień i trudu życia, jako ofiary dla Chrystusa, dla bliźnich pogrążonych w nałogach;

- czytania i rozpowszechniania w miarę możliwości prasy katolickiej i trzeźwościowej w celu pogłębiania swojej wiedzy i kształtowania właściwych postaw;

- pozyskiwania nowych członków do MRT, szczególnie ze swego najbliższego otoczenia; 
- przestrzegania ABC Społecznej Krucjaty Miłości Prymasa Tysiąclecia Kard. Stefana Wyszyńskiego w swoim codziennym życiu.

Każdy dorosły przyjaciel i miłośnik RTMK ma prawo wybierać, a także może być wybranym do pełnienia różnych funkcji w parafialnych, diecezjalnych i krajowych apostolatach i ogniwach Ruchu Trzeźwości, może uczestniczyć w realizacji lokalnych programów apostolstwa trzeźwości. Wszyscy członkowie MRT korzystają z modlitw, odpustów i owoców brackich Mszy św. zarówno za życia jak i po śmierci, mają prawo do noszenia odznak członkowskich, jako symboli ruchu, oraz posiadają swój sztandar z emblematami zawierającymi po jednej stronie św. Maksymiliana Kolbego z nazwą ruchu i parafii w której istnieje, a po drugiej stronie wizerunek Matki Bożej Częstochowskiej z napisem „Królowo Polski błogosław Narodowi na życie w trzeźwości”.

Maksymiliański Ruch Trzeźwości działając przy parafii, współpracuje $\mathrm{z}$ przychodniami zdrowia, zakładami odwykowymi w zakresie leczenia choroby alkoholowej i innych uzależnień oraz instytucjami opiekującymi się rodziną osoby uzależnionej, niosąc jednocześnie konkretną pomoc potrzebującym. Współpracuje również ze stowarzyszeniami, instytucjami prowadzącymi walkę $\mathrm{z}$ alkoholizmem i innymi uzależnieniami, oraz z Seminarium Duchownym kształcącym i przygotowującym przyszłych kapłanów ${ }^{18}$.

\section{WYMIAR DUSZPASTERSKI MRT}

Maksymiliański Ruch Trzeźwości jako Kościelny Apostolat Trzeźwości zgodnie z postanowieniem Konferencji Episkopatu Polski posiada kościelną strukturę terytorialną, dlatego miejscem jego istnienia i działania są diecezje, dekanaty oraz parafie. Siedzibą i miejscem spotkań MRT $\mathrm{w}$ parafii jest pomieszczenie $\mathrm{w}$ domu parafialnym, wyznaczone przez administratora parafii.

18 Por. Komisja Episkopatu Polski ds. Trzeźwości, Ramowy Regulamin Ruchu Trzeźwości im. św. Maksymiliana Kolbego, s. 6-14. 
Opiekunem i moderatorem MRT jest kapłan, który swoim przykładem powinien pociągać innych do szerzenia trzeźwości i abstynencji. Jak mówił Ks. Kardynał Stefan Wyszyński: „Przez całkowitą abstynencję duchowieństwa katolickiego do trzeźwości całego narodu polskiego" ${ }^{19}$. Jako duszpasterz ruchu, kapłan musi przede wszystkim postawić na zaufanie między sobą a ludźmi świeckimi, na dobrą wolę i wzajemną pomoc, bez których niemożliwe będzie istnienie i prowadzenie RTMK, oraz włączanie w ten ruch jak największej liczby osób świeckich. Zadaniem duszpasterza w RTMK jest otaczanie ciągłą i systematyczną opieką członków MRT, organizowanie dla nich comiesięcznych nabożeństw i spotkań duszpastersko-apostolskich, przede wszystkim wdrażanie w ich życie maksymiliańskiej idei i programu RTMK. Kapłan będący duszpasterzem i opiekunem ruchu powinien odznaczać się umiejętnością zafascynowania dorosłych, młodzieży i dzieci chrześcijańską wizją życia w miłości, wolności, radości dzieci Bożych. Powinien odznaczać się umiejętnością stosowania pozytywnych metod wychowawczych w stosunku do tych, którzy zostali mu powierzeni, aby uczyć ich dojrzałej postawy wobec picia alkoholu, a przede wszystkim uczyć dojrzałej postawy wobec życia, czyli pomagać zająć odpowiedzialną postawę wobec ciała, myślenia, emocji, wobec sfery duchowej, moralnej i społecznej ${ }^{20}$.

Członkiem Maksymiliańskiego Ruchu Trzeźwości może być każdy katolik, poczynając od chwili przyjęcia I Komunii św. W zależności od stopnia zaangażowania $\mathrm{w}$ apostolstwo trzeźwości istnieją trzy rodzaje członków: sympatycy wspierający, przyjaciele oraz miłośnicy. Członkowie-sympatycy wspierający to osoby dorosłe, które zobowiązują się tylko we własnym sumieniu zachować zupełną lub częściową wstrzemięźliwość, a szczególnie przestrzegać osobistej abstynencji w sierpniu. Z kolei przyjaciele apostolstwa trzeźwości w zależności od wieku mają zróżnicowane zobowiązania: dzieci i młodzież zachowują zupełną abstynencję od wszelkich napojów alkoholowych i tytoniu do ukończenia 21 roku życia, a od

19 Por. Apostoł trzeźwości. Vademecum duszpasterstwa trzeźwości, Płock 2010, s. 21; Komisja Episkopatu Polski ds. Trzeźwości, Ruch Trzeźwości im. św. Maksymiliana Kolbego nadzieja ratowania Narodu (do użytku wewnętrznego), Warszawa 1984, s. 1.

${ }^{20}$ Por. Komisja Episkopatu Polski ds. Trzeźwości, Ruch Trzeźwości im. św. Maksymiliana Kolbego nadzieją ratowania Narodu, s. 4-5; M. Dziewiecki, Z teki duszpasterza, „Trzeźwymi Bądźcie”, 4 (1999), s. 23. 
narkotyków na całe życie, dorośli po skończonym 21 roku życia zachowują wstrzemięźliwość od wszelkich napojów alkoholowych na całe życie, lub przynajmniej na okres roku, z możliwością odnawiania przyrzeczeń w kolejnych latach. Trzeci rodzaj członków - miłośnicy apostolstwa trzeźwości - to osoby dorosłe, które zobowiązują się zachować dobrowolną, całkowitą abstynencję od wszystkich napojów alkoholowych przez całe życie, która wynika z motywu miłości Boga i bliźniego. Członkowie: przyjaciele i miłośnicy swoje przyrzeczenia składają $\mathrm{w}$ formie pisemnego oświadczenia, które zawiera również zobowiązanie na miarę ich możliwości do apostolstwa w ramach $\mathrm{RTMK}^{21}$.

\section{DZIAŁALNOŚĆ MAKSYMILIAŃSKIEGO RUCHU TRZEŹWOŚCl PRZY PARAFIl}

Ruch Trzeźwości im. św. Maksymiliana Kolbego proklamowany na Jasnej Górze 19 września 1982 roku podczas I Krajowej Pielgrzymki Apostolstwa Trzeźwości jest zorganizowaną formą parafialnego duszpasterstwa zwyczajnego, jego integralną i niezbywalną częścią, działającą przy parafiach. MRT działając przy parafii nie wymaga zgody władz państwowych, ani odrębnej rejestracji urzędach zajmujących się problemem uzależnień. Działa jedynie w oparciu o wytyczne Komisji Episkopatu Polski w porozumieniu z proboszczem i władzami kościelnymi. Nie wymaga szczególnych nakładów finansowych i jest dostępny dla każdego. Pomaga ludziom dotkniętym problemem alkoholowym: dorosłym, dzieciom, całym rodzinom. Mówiąc o MRT należy również zwrócić uwagę na fakt, iż moderatorem i duszpasterzem ruchu jest kapłan posługujący w danej parafii, znający dobrze to środowisko i ludzi w nim mieszkających, zawsze dostępny również w konfesjonale, a tym samym zwiększający skuteczność działania MRT. Takim przykładem działalności MRT przy parafii są dwa ruchy działające w Gdańsku założone przez księdza Bogusława Głodowskiego -długoletniego duszpasterza trzeźwości Diecezji gdańskiej.

${ }^{21}$ Por. Komisja Episkopatu Polski ds. Trzeźwości, Ramowy Regulamin Ruchu Trzeźwości im. św. Maksymiliana Kolbego, s. 9-11. 
Pierwszym z nich jest Ruch Trzeźwości powstały i działający przy parafii NMP Królowej Różańca Świętego na Gdańskim Przymorzu założony przez ks. Bogusława Głodowskiego który będąc młodym kapłanem pracował w tutejszej parafii. Znając dobrze środowisko z wizyt duszpasterskich i posługi w kościele mógł dotrzeć do tych, którzy mieli problem alkoholowy w rodzinie. Niesienie pomocy umożliwiało mu wcześniejsze przygotowanie w tym zakresie, ponieważ o uzależnieniu od alkoholu uczył się podczas studiów w Seminarium oraz jeżdżąc na kursy do Ośrodka Apostolstwa Trzeźwości w Zakroczmiu. Misją przewodnią powstałego z inicjatywy ks. Bogusława Głodowskiego Maksymiliańskiego Ruchu Trzeźwości w parafii NMP Królowej Różańca Świętego w Gdańsku było i jest dzielenie się doświadczeniem, siłą i nadzieją życia w trzeźwości, uczenie się budowania na nowo życia rodzinnego i towarzyskiego w oparciu o zdrowe zasady, a szczególnie prowadzenie profilaktyki i rzetelna informacja na temat alkoholizmu, który niszczy nie tylko pijącego, ale także rodzinę i społeczeństwo. Propagowanie trzeźwości i abstynencji ma miejsce zarówno wśród samych członków ruchu, ich rodzin i przyjaciół, ale również we wspólnocie parafialnej i poza nią. Początkowo Maksymiliański Ruch Trzeźwości tworzyła niewielka grupa osób uczestnicząca już wcześniej w nabożeństwach ekspiacyjnych za grzechy pijaństwa w rodzinach, w parafii, w narodzie polskim, organizowanych przez księdza Bogusława Głodowskiego znanego jako ksiądz Bogdan, który był pierwszym opiekunem i duszpasterzem tego ruchu. Jego członkowie dobrowolnie podejmują abstynencję w myśl hasła: „Przez abstynencję wielu do rzeźwości wszystkich”, dając dobry przykład w swojej rodzinie, parafii, zakładzie pracy. W każdą pierwszą środę miesiąca o godzinie dziewiętnastej odprawiana jest Msza św. w intencji trzeźwości rodzin należących do Maksymiliańskiego Ruchu Trzeźwości, oraz trzeźwości narodu polskiego. Po Mszy św. w salce parafialnej przy dolnym kościele można wysłuchać świadectw osób z problemem alkoholowym, którzy odnaleźli drogę do trzeźwości, a także rodzin dotkniętych tym problemem. Oprócz comiesięcznej Mszy św., Maksymiliański Ruch Trzeźwości na Gdańskim Przymorzu w pierwszych latach swojej działalności prowadził cotygodniowe spotkania dla wszystkich członków i sympatyków, którzy dzieląc się swoimi problemami, wymieniając się doświadczeniami w walce z uzależnieniem od alkoholu, a także zapoznając się z zagadnieniami dotyczący- 
mi istoty choroby alkoholowej, jej przebiegu w poszczególnych okresach, oraz wychodzenia z niej. Tutaj mogą również dowiedzieć się, czym jest trzeźwość i jak bardzo ważna jest w życiu każdego człowieka. Do ruchu zaczynają przychodzić osoby uzależnione od alkoholu i ich rodziny szukające pomocy i wsparcia w wychodzeniu z uzależnienia i współuzależnienia. Ruch Trzeźwości im. św. Maksymiliana Kolbego powstały przy parafii NMP Królowej Różańca Świętego w Gdańsku zaczyna przyciągać również tych, którzy jako przyjaciele i sympatycy, pragną także budować swoje życie oparte na trzeźwości. Grupa, która liczy początkowo kilka osób liczebnie rozwija się. Wśród nich są tacy, którzy podjęli abstynencję do końca życia. Kilka osób z ruchu wyjeżdża na kurso-rekolekcje do Zakroczymia, a zdobytą tam wiedzę przekazują innym, zachęcając w ten sposób do wzięcia udziału w następnych rekolekcjach. W niedługim czasie po powstaniu Maksymiliańskiego Ruchu Trzeźwości w parafii, członkowie tego ruchu wraz ze swoim opiekunem i duszpasterzem ks. Bogdanem występują do proboszcza parafii ks. Jana Majdera z inicjatywą założenia Księgi Trzeźwości. W księdze tej członek, jak również każdy parafianin, z okazji świąt RTMK, Tygodnia Modlitw o Trzeźwość Narodu, misji, rekolekcji, odpustu parafialnego, Wielkiego Postu, Adwentu itp. może wpisać swoje postanowienia wstrzemięźliwości czy abstynencji od napojów alkoholowych, nikotyny i innych zniewoleń na określony czas lub do końca życia, ofiarowując je Bogu za siebie lub innych. Księga Trzeźwości służy zarówno MRT, jak i całej wspólnocie parafialnej w dążeniu do życia $\mathrm{w}$ trzeźwości, oraz jest dla innych świadectwem tych, którzy podejmują tego rodzaju postanowienia W rozwijającym się Ruchu Trzeźwości na Gdańskim Przymorzu, który gromadzi coraz więcej osób, zostaje opracowany przez duszpasterza trzeźwości i jego członków szczegółowy plan pracy na dalsze lata działalności. Opracowanie planu potrzebne było po to, aby Ruch mógł dobrze służyć osobom z parafii i diecezji potrzebującym pomocy oraz by były realizowane cele i zadania zawarte w Ramowym Regulaminie Ruchu Trzeźwości im. Maksymiliana Kolbego. Cele i zadania MRT na Przymorzu to przede wszystkim spotkania formacyjne i formacja duchowa członków Ruchu Trzeźwości mająca na celu ich dojrzewanie w wierze i życie w trzeźwości. W ramach formacji, oprócz comiesięcznych Mszy św. trzeźwościowych i cotygodniowych spotkań w salce parafialnej, odbywają się organizowane dla członków 
ruchu różnego rodzaju wspólne wyjazdy. Należą do nich autokarowe pielgrzymki trzeźwościowe połączone $\mathrm{z}$ nawiedzaniem różnych sanktuariów Maryjnych w Polsce, a także związanych z patronem trzeźwości św. Maksymilianem Kolbe, które mają pomagać w pogłębianiu wiary, trzeźwości i abstynencji, oraz umacniać i rozwijać relacje międzyludzkie budowane na spotkaniach w salce parafialnej w ciągu roku. Inną formą wyjazdową pomagającą w formacji członków Maksymiliańskiego Ruchu są rekolekcje i dni skupienia połączone z czytaniem i rozważaniem Pisma Świętego, które jest podstawą życia chrześcijańskiego. Wyjazdy te mają pomagać w pogłębianiu motywacji do życia w trzeźwości, odbudowywaniu wiary, udziału wiary w procesie przebaczania i budowania poczucia własnej wartości. Ma to być czas pozwalający na odreagowanie negatywnych uczuć, przeżyć, leków, czas odbudowywania relacji międzyludzkich, rodzinnych, małżeńskich, budowania pozytywnego życia małżeńskiego i rodzinnego. Kolejnym elementem działalności Maksymiliańskiego Ruchu Trzeźwości w parafii NMP Królowej Różańca Świętego na Gdańskim Przymorzu są też zadania realizowane na rzecz krzewienia trzeźwości w tutejszej parafii. Należą do nich: współpraca z proboszczem i innymi kapłanami parafii, czynne włączanie się Maksymiliańskiego Ruchu Trzeźwości w życie parafii, raz w miesiącu Msza św. w intencji o trzeźwość; dawanie świadectw przez trzeźwych alkoholików i ich rodziny w Wielkim Poście; sierpniu - miesiącu trzeźwości czy w Adwencie; prowadzenie Drogi Krzyżowej w intencji trzeźwości w Wielkim Poście, organizowanie zabaw bezalkoholowych, sylwestrowych i karnawałowych, mających na celu pokazanie, że można bawić się bez alkoholu, pomaganie ludziom, którzy potrzebują pomocy $\mathrm{w}$ powstaniu z jakiegokolwiek uzależnienia, a także pomoc rodzinom takich osób, organizowanie wyjazdów na letni wypoczynek dla dzieci z rodzin dysfunkcyjnych i otaczanie ich opieką w ciągu roku, propagowanie rekolekcji duszpasterstwa trzeźwości w Zakroczymiu. W planie pracy Maksymiliańskiego Ruchu Trzeźwości na Przymorzu znajduje się również współpraca z kapłanami z innych parafii, oraz Gdańskim Seminarium Duchownym w Oliwie. Współpraca ta ma na celu ukazanie zagrożeń wynikających z nadużywania alkoholu, jego destrukcyjnego wpływu nie tylko na osobę pijąca, ale również na jej rodzinę: współmałżonka, rodziców a szczególnie dzieci. Ma też wskazywać drogi wychodzenia z zaklętego kręgu, jakim jest alkoholizm i inne uza- 
leżnienia. Ma przede wszystkim uwrażliwiać kapłanów i kleryków, którzy w przyszłości będą kapłanami, na problem uzależnień, aby skutecznie umieli pomagać tym, których ten problem dotyka, a także aby ukazywali trzeźwość jako jedną z podstawowych wartości w życiu każdego człowieka. Kolejnym ważnym punktem planu pracy jest współpraca MRT z innymi ruchami i grupami samopomocowymi działającymi na polu trzeźwości w parafii, diecezji i kraju. Ma ona na celu dzielenie się nadzieją, siłą i doświadczeniem w walce o trzeźwość człowieka, o odrodzenie moralne w Ojczyźnie. Z rozwijającego się i prężnie działającego Maksymiliańskiego Ruchu Trzeźwości na Przymorzu powstały grupy samopomocowe, takie jak: AA - wspólnota ludzi uzależnionych od alkoholu, oraz Al-Anon, wspólnota rodzin, w których występuje problem alkoholowy Założony przez tego kapłana przy parafii Ruch Trzeźwości Maksymiliana Kolbego pomagał, i wciąż pomaga, ludziom dotkniętym tym problemem: dorosłym i dzieciom - całym rodzinom.

Drugim ruchem prężnie działającym w Gdańsku jest MRT przy parafii św. Rafała Kalinowskiego w Gdańsku Złotej Karczmie. Powstał on we wrześniu 1999 roku z inicjatywy ks. Bogusława Głodowskiego, który jest opiekunem tego ruchu przez te wszystkie lata. Maksymiliański Ruch Trzeźwości działa nieprzerwanie do tej pory gromadząc przede wszystkim członków ruchów samopomocowych i rodzin z parafii, sympatyków i przyjaciół, wszystkich, którzy przyjmują zasadę swojego życia - trzeźwość i abstynencję opartą na Chrystusowej Ewangelii. Czerpiąc z założeń Ramowego Regulaminu Ruchu Trzeźwości im. św. Maksymiliana Kolbego opracowanego przez Komisję Episkopatu Polski ds. Trzeźwości MRT $\mathrm{w}$ naszej parafii realizuje zadania, które zostały nakreślone u początku jego powstania przez założyciela i jednocześnie duszpasterza i opiekuna tego ruchu, którym jest ksiądz Bogusław Głodowski oraz jego pierwszych członków. Do zadań tych należą między innymi spotkania formacyjne i formacja duchowa, działalność duszpasterska w Ruchu, krzewienie trzeźwości w parafii, współpraca z kapłanami z innych parafii i Gdańskim Seminarium Duchownym, a także współpraca z innymi ruchami i grupami samopomocowymi działającymi na polu trzeźwości.

Spotkania formacyjne i formacja duchowa, oraz związana $\mathrm{z}$ tym działalność duszpasterska w MRT w Złotej Karczmie to przede wszystkim spotkania, które niezmiennie od samego początku są w każdą drugą 
środę miesiąca o godzinie 18 na Mszy św., podczas której członkowie ruchu czytają wprowadzenie do Mszy św przybliżając wiernym MRT, oraz modlitwę wiernych, którą sami układają, dając tym samym świadectwo życia w trzeźwości innym ludziom. Po mszy odbywają się spotkania formacyjne $\mathrm{w}$ salce parafialnej pod kierunkiem duszpasterza i opiekuna MRT - księdza Bogdana. Podczas tych spotkań prowadzone są katechezy na temat życia w trzeźwości w oparciu o wybrany fragment Pisma Świętego czy też nauczanie Jana Pawła II. W prowadzenie tych katechez włączani są poszczególni członkowie ruchu, co pomaga pogłębić jeszcze bardziej swoje życie w trzeźwości. Ważnym elementem formacji duchowej członków MRT w Gdańsku - Złotej Karczmie są co roku organizowane nieprzerwanie od samego początku pielgrzymki trzeźwościowe, między innymi na ogólnopolską pielgrzymkę ruchów trzeźwościowych do Częstochowy w II niedzielę czerwca. W ramach formacji duchowej często organizowane są wyjazdy dla członków MRT na trzydniowe rekolekcje, a w lipcu każdego roku są wyjazdy całymi rodzinami na dwutygodniowe wakacje z Bogiem. MRT wraz ze swoim opiekunem ks. Bogusławem Głodowskim organizuje wiele innych spotkań rodzinnych, gdzie wszyscy należący do ruchu uczą się nowego - trzeźwego stylu życia. Krzewienie trzeźwości $\mathrm{w}$ parafii oprócz comiesięcznych mszy trzeźwościowych to przede wszystkim aktywne włączanie się w życie parafii poprzez między innymi: różaniec w październiku, w Wielkim Poście - Tydzień Modlitw o Trzeźwość Narodu Polskiego, Droga Krzyżowa, organizowanie sylwestra bezalkoholowego i zabaw karnawałowych dla rodzin z parafii, organizowanie wypoczynku dla dzieci zimą i latem. Każdego roku MRT pomaga przy organizacji i bierze aktywny udział w trzeźwościowej diecezjalnej pieszej pielgrzymce z Oliwy do Matemblewa 15 sierpnia, a w styczniu aktywnie włącza się w organizację spotkania opłatkowego dla wszystkich ruchów trzeźwościowych Diecezji Gdańskiej. Niezmiennie od początku istnienia MRT przy parafii członkowie ruchu i ich rodziny spotykają się z klerykami i wykładowcami Seminarium Duchownego w Oliwie podczas Adwentu na wspólnym nabożeństwie, a potem spotkaniu gdzie dzielą się swoim świadectwem życia w trzeźwości, w Wielkim Poście z kolei uczestniczą w Drodze Krzyżowej organizowanej przez kleryków dla duszpasterstwa trzeźwości i wspólnot samopomocowych diecezji na krużgankach pocysterskich. Takie coroczne spotkania mają pomóc kle- 
rykom, gdy jako kapłani zetkną się z problemem choroby alkoholowej w pracy duszpasterskiej. Maksymiliański Ruch Trzeźwości w Gdańsku Złotej Karczmie poprzez kolejne lata swego istnienia współpracuje z różnymi kapłanami Diecezji Gdańskiej. Członkowie ruchu zapraszani są do różnych parafii, szczególnie w Adwencie, Wielkim Poście i sierpniu, który jest miesiącem trzeźwości, aby mówić na temat uzależnień, oraz zgubnych skutków nadużywania alkoholu, a także aby dawać świadectwo ze swojego życia. Ta forma działalności ma pomóc kapłanom zrozumieć, czym jest choroba alkoholowa, jakie wynikają z niej konsekwencje nie tylko dla pijącego, ale i dla całej rodziny, aby mogli skutecznie wspierać tych parafian, którzy tej pomocy potrzebują, a w odniesieniu do osób żyjących w danej parafii spotkania tego typu uczą życia w trzeźwości i wskazują, gdzie należy szukać pomocy dla siebie i bliskich dotkniętych problemem alkoholowym. W ramach Maksymiliańskiego Ruchu Trzeźwości działa Róża Różańcowa, złożona z całych rodzin.

RTMK na Gdańskim Przymorzu i w Gdańsku - Złotej Karczmie poprzez dzielenie się swoim doświadczeniem i własnym przykładem nie tylko w parafii, ale w całej Archidiecezji Gdańskiej, ukazywał i nadal ukazuje drogę do życia w trzeźwości i wolności nie tylko ludziom poranionym przez alkohol, ale także tym, którzy tego problemu nie mają. Ludzie, którzy odnaleźli swoją drogę poprzez Maksymiliański Ruch Trzeźwości, są ludźmi szczęśliwymi, pełnymi radości i pogody ducha, wolnymi od wszelkich uzależnień, umiejącymi radzić sobie z trudnościami i przeciwnościami życiowymi krocząc drogą przykazań Bożych i pokazując innym drogę do życia wolnego od wszelkich uzależnień .

Jednak, aby mógł tak działać RTMK potrzebny jest kapłan taki jak ks. Bogdan, który wie. co to jest choroba alkoholowa i jak może niszczyć nie tylko tego co nadużywa alkoholu, ale całe rodziny, które najbardziej cierpią - szczególnie dzieci, dlatego potrzeba nam coraz więcej takich kapłanów.

\section{ZAKOŃCZENIE}

Opisane w tym artykule zagadnienia ukazują jak ważna i uzasadniona jest troska Kościoła o człowieka i realizację jego życia w pełni 
ewangelicznego, troska o trzeźwość - będącą jedną z podstawowych wartości człowieka. Dążenia te wspierają organizacje i stowarzyszenia, których przykładem są ukazane $\mathrm{w}$ tym rozdziale bractwa trzeźwości, zwłaszcza Ruch Trzeźwości Maksymiliana Kolbego. Działały one i działają w Polsce w różnych okresach historycznych i ukazują formy troski o trzeźwość człowieka realizowane przez Kościół. Prezentując działalność MRT, nie sposób nie dostrzec, jak istotne jest zakładanie takich ruchów trzeźwości przy każdej parafii i jak niezwykle ważna jest rola kapłana będącego opiekunem takiego ruchu trzeźwości w pokonywaniu słabości. Ich działalność w parafiach umożliwia ludziom, którzy potrzebują wsparcia, uzyskanie stosownej pomocy dla wzrastania w człowieczeństwie i w wierze. Zachętą do zakładania MRT przy parafiach niech będą słowa św. Jana Pawła II wypowiedziane do Polaków w dniu 23 X 1978 r., aby skutecznie przeciwstawiali się obyczajom zagrażającym człowiekowi, jego rodzinie i narodowi.

Streszczenie. Kościół w trosce o człowieka, o jego rozwój w całym wymiarze cielesno-duchowym i realizację życia w pełni ewangelicznego zgodnie z nauką Soboru Watykańskiego II oraz w obliczu narastającego alkoholizmu, prowadzi różne formy działalności trzeźwościowej. Jedną z takich form działalności jest Ruch Trzeźwości im. św. Maksymiliana Kolbego działający przy parafiach, reaktywowany przez Episkopat Polski w 1982 roku na Jasnej Górze, którego celem jest walka z pijaństwem oraz szerzenie trzeźwości kształtującej w człowieku jego godność, miłość, wolność i odpowiedzialność. MRT jest żywą odpowiedzią Kościoła w Polsce na prośbę dwóch wielkich Polaków: sługi bożego ks. kardynała Stefana Wyszyńskiego, któremu sprawa trzeźwości Narodu Polskiego była szczególnie bliska, o której mawiał: „przez abstynencję wszystkich kapłanów do trzeźwości całego Narodu”, oraz na prośbę św. Jana Pawła II wyrażoną do Polaków w dniu 23 X 1978 roku - aby skutecznie przeciwstawiali się obyczajom zagrażającym człowiekowi, jego rodzinie i narodowi.

Słowa kluczowe: Maksymiliański Ruch Trzeźwości; Kościół; formy działalności trzeźwościowej; trzeźwość całego Narodu; troska o człowieka.

Abstract. Sobriety as the main goal and task of Maximilian Sobriety Movement. Church for the sake of man, for his development of the whole dimension of corporeal and spiritual life and the realization of fully evangelic life, according to the teachings of the Second Vatican Council and in the face of the growing alcoholism, conducts various sobriety activities. One of these activities is the St. Maximilian Kolbe Sobriety Movement which is operating in parishes, reactivated by the Polish Episcopate 
in 1982 at Jasna Gora, whose aim is to fight against the spread of drunkenness and propagation of the sobriety in shaping human dignity, love, freedom and responsibility. MRT is a living response to the Church in Poland at the request of two great Poles: Servant of God Father-Cardinal Stefan Wyszynski, to whom the sobriety subject of the Polish Nation was particularly close. He used to say: "by the abstinence of all priests to the sobriety of the whole nation," and at the request of St. John Paul II, expressed to the Poles on 23 X 1978 year - to effectively oppose the customs threatening human, his family and the nation.

Key words: Maximilian Sobriety Movement; the Church; forms of sobriety action; sobriety of the whole nation; concern for human.

\section{BIBLIOGRAFIA}

Chodźko, W., Walka z alkoholizmem w okresie między obu wojnami światowymi, „Roczniki UMCS”, 3 (1948), 2 SEC D, s. 87-93.

Dziewiecki, M., Nowe przestanie nadziei, Warszawa 2000

Dziewiecki, M., Z teki duszpasterza, „Trzeźwymi Bądźcie”, 4 (1999), s. 23.

Głodowski, B., Historia ruchów trzeźwościowych na Pomorzu, cz. 1, „Trzeźwymi Bądźcie”, 1 (2004), s. 15-17

Głodowski, B., Historia ruchów trzeźwościowych na Pomorzu, cz. 2, „Trzeźwymi Bądźcie”, 2 (2004), s. 30-32.

Głodowski, B., Zaangażowanie duchowieństwa katolickiego $w$ ruch trzeźwościowy na Pomorzu przed rokiem 1920, „Studia Gdańskie”,26 (2007), s. 143-172.

Jan Paweł II, List do Polaków. Zachowajcie wierność Chrystusowi, Jego Krzyżowi, Kościołowi. 24 X 1978, w: Nauczanie Papieskie, t. 1, opr. E. Weron, A. Jaroch, Poznań-Warszawa 1987, s. 23.

Komisja Episkopatu Polski d/s. Trzeźwości, Ramowy Regulamin Ruchu Trzeźwości im. św. Maksymiliana Kolbego, Warszawa 1986, s. 6-14.

Komisja Episkopatu Polski ds. Trzeźwości, Ruch Trzeźwości im. św. Maksymiliana Kolbego nadzieją ratowania Narodu, (do użytku wewnętrznego), Warszawa 1984, s. 1-5.

Komisja Episkopatu Polski, Wytyczne Episkopatu Polski dla Kościelnej działalności trzeźwościowej, Warszawa 1 IV 1971, s. 1.

Kronika MRT przy parafii NMP Królowej Różańca Świętego, Gdańsk-Przymorze 1985.

Kronika MRT przy parafii św. Rafała Kalinowskiego, Gdańsk-Złota Karczma 1999.

Padacz, Wł., Katolicka akcja trzeźwościowa w Polsce porozbiorowej, „Homo Dei” 1 (1963), s. 27-33.

Radziłłowicz, R., Alkohologia, książka dla walczacych z alkoholizmem, Warszawa 1928.

Romaniuk, P., W trosce o trzeźwość Narodu. Sylwetki najwybitniejszych działaczy trzeźwościowych XIX $i$ XX w., t. 2, Warszawa 1996. 
Walewander E., Wychowanie chrześcijańskie w nauczaniu i praktyce Kościoła katolickiego na ziemiach polskich w II połowie XIX w., Lublin 1994.

Zespół Apostolstwa Trzeźwości przy Konferencji Episkopatu Polski, Apostoł trzeźwości. Vademecum duszpasterstwa trzeźwości, Płock 2006.

Zespół Apostolstwa Trzeźwości przy Konferencji Episkopatu Polski, Apostoł Trzeźwości. Vademecum duszpasterstwa trzeźwości, Płock 2007.

Zespół Apostolstwa Trzeźwości przy Konferencji Episkopatu Polski, Apostoł trzeźwości. Vademecum duszpasterstwa trzeźwości, Płock 2010. 